\title{
WANITA DAN HUKUM \\ PERSPEKTIF FEMINIS TERHADAP HUKUM
}

\author{
Oleh Rahmawati Baharuddin*
}

\begin{abstract}
ABSTRAKSI
Kaum feminis menegaskan bahwa bagian terbesar dalam hukum merupakan legitimasi terhadap sebuah ideologi yang dominan, dan bahwa bagian terbesar dari ideologi yang dominan dari kebanyakan masyarakat adalah bercirikan patriarkhis. Fokus dari kritik hukum feminis belakangan ini merupakan hasil dari sebuah penemuan bahwa norma-norma seringkali disisipi bias yang mempertegas subordinasi perempuan terhadap laki-laki.

Meskipun pada dasarnya gugatan para teoritisi hukum feminis terhadap. sistem hukum begitu luas dan beragam, setidaknya ada benang merah yang bisa diambil, yaitu bahwa kerangka hukum yang telah mapan sangat bersifat phallosentris (didominasi kaum pria), dan merupakan wahana untuk menciptakan dominasi laki-laki menjadi semakin kokoh dan sah dengan mengadopsi sudut pandang laki-laki terhadap hukum, dan pada saat bersamaan ia juga memperkuat gagasan tersebut di tengah masyarakat. Dengan demikian melalui jalur hukum, dominasi laki-laki dicitrakan sebagai ciri khas kehidupan, bukan sebagai pemahaman satu pihak yang dipaksakan untuk keuntungan kelompok yang paling dominan.
\end{abstract}

Kata kunci: patriarkhi, feminisme, kesetaraan, teori hukum

\section{Pendahuluan}

Menurut kaum feminis, kekuasaan ideologi patriarkhis begitu besar sehingga ia merembes ke dalam seluruh pranata budaya kita: hukum, politik, pemikiran sosial dan ekonomi, yang selama berabad-abad didasarkan pada penerimaan terhadap kebiasaan, prinsip-prinsip dan rasionalisasi yang membagi peran berbeda untuk laki-laki dan perempuan atas dasar pandangan bahwa alam telah menentukan hakikat peran-peran tersebut (Curzon, 1995).

Patriarkhi adalah sebuah struktur sosial yang dicirikan dengan dominasi laki-laki, disertai dengan seperangkat ideologi yang berupaya melakukan 
pembenaran terhadap tatanan tersebut, dan teori hukum yang menafsirkan hukum dari sudut pandang yang dicirikan dengan sebuah keyakinan, baik eksplisit maupun implisit, terhadap ketidaksetaraan yang sangat mendasar. Definisi lain tentang patriarkhi diberikan oleh Prof. Janet Rifkin dalam sebuah essaynya yang otoritatif, Toward a Theory of Law and Patriarchy (1980) sebagai "segala bentuk pengorganisasian kelompok di mana para laki-lakinya memegang kekuasaan dominan, dan menentukan bagian mana yang boleh dan tidak boleh diperankan oleh perempuan, di mana kecakapan yang diserahkan kepada perempuan dialihkan secara umum kepada hal-hal yang bersifat mistik, estetik, sambil mencegah perannya di dunia praktis dan politis, yang dipandang sebagai dunia khusus laki-laki yang terpisah dengan dunia perempuan." Istilah "patriarkhi" digunakan pada masa sebelumnya untuk merujuk pada sebuah sistem masyarakat yang dikuasai oleh laki-laki, sebagai keturunan dari jalur laki-laki; sistem tersebut kini masih dipakai dalam pengertian yang lebih luas, dengan rujukan khusus tidak hanya pada sebuah masyarakat yang telah dibangun berdasarkan dominasi laki-laki, tapi juga merujuk pada ideologi yang berupaya melakukan pembenaran terhadap dominasi tersebut (Curzon, 1995).

Teori hukum feminis menafsirkan masyarakat patriarkhis dalam terminologi yang tegas: ia merupakan sebuah masyarakat yang didasarkan pada hirarki yang menggunakan paradigma hukum sebagai simbol otoritas dan dominasi laki-laki. Ia harus digugat dengan berbagai cara, yang melibatkan penyelidikan menyeluruh atas asal-usul, lembaga dan ideologinya (terutama dalam kaitannya dengan hukum). Menurut doktrin hukum feminis, melemahnya sistem patriarkhis merupakan persyaratan bagi penciptaan "hukum baru" dan institusi hukum yang diperlukan untuk memperkenalkan dan mempertahankan "masyarakat yang ideal" di mana tidak ada lagi diskriminasi dalam praktek hukum dan sosial (Curzon: 1995).

Oleh karena itu sebuah analisa tentang sistem hukum patriarkhis, penelitian sejarahnya, kandungan ideologinya dan, di atas semuanya, dampaknya terhadap teori hukum kontemporer dan praktek hukum merupakan inti dari ideologi gerakan hukum feminis. Pengakuan dan penolakan terhadap patriarkhi dipandang oleh para ahli hukum feminis memiliki implikasi yang revolusioner terhadap masyarakat pada umumnya dan terhadap sistem hukum kontemporer pada khususnya. Di sisi lain, komitmen untuk melenyapkan tatanan patriarkhis merupakan komitmen untuk melakukan perubahan besar terhadap institusi sosial dan hukum yang sangat mendasar. 


\section{Membongkar Dominasi Patriarkhi Dalam Teori Hukum}

Teori hukum feminis mewakili sebuah perkembangan modern yang paling penting dalam metode analisa hukum, yang membahas perlakuan terhadap perempuan dalam sistem hukum, dan persepsi terhadap pengalaman dan kebutuhan perempuan dalam hukum. Dalam melaksanakan agendanya ini, teori hukum feminis tidak hanya berupaya mengenali dan membantah sistem hukum yang secara tradisional berorientasi patriarkhis, tapi juga mempertanyakan teori dan ideologi yang berorientasi patriarkhis. Pemikiran feminis ini berupaya mencari pemahaman secara kontekstual terhadap hukum yang merupakan konstruksi sosial sebagai hasil dari beragam pengaruh, yang diantaranya bahkan tidak dikenali lagi asal-usulnya. Hal ini pada gilirannya menuntut sebuah metodologi baru yang radikal dalam teori hukum (Hilaire and Nigel, 1999).

Dalam tradisi Islam, rekontruksi terhadap teks-teks keagamaan yang selama ini tersimpan rapi dalam 'otoritas' keulamaan radisional harus lebih diprioritaskan karena merupakan sumber ketimpangan hubungan laki-laki dan perempuan dalam masyarakat Islam. Ajaran-ajaran tersebut telah menjadi sumber legitimasi peminggiran perempuan dalam wilayah sosial, politik, dan hukum baik dalam lingkup publik maupun domestik. Kelompok feminis Islam, yang diwakili di antaranya oleh Fatima Mernissi, Rifat Hassan, Leila Ahmed, dan Ali Asghar Engineer, malah berpendapat bahwa ide normatif Islam sesungguhnya mengusung nilai-nilai feminis yang telah dijungkirbalikan oleh pelaku-pelaku sejarah yang memiliki watakmisoginis. Karena itu tugas penting yang harus dilakukan adalah merekonstruksi seluruh tradisi keagamaan patriarkis yang telah berurat berakardalam radisi Islam selama berabad-abad.

Konstruksi patriarkis yang sangat kuat terhadap perempuan ditemukan dalam kitab fikih al-munakahah, kitab tentang aturan berumah tangga yang banyak dipakai di kalangan penganut mazhab Syafi'i. Dalam konsep nikah, misalnya, perempuan hanya menjadi objek laki-laki. Semua itu terjadi karena dalam ijab kabul yang merupakan pintu masuk ke gerbang perkawinan, seolaholah laki-laki menjadi pembeli dan perempuan sebagai komoditi yang dibeli. Hal ini akan memberi peluang laki-laki untuk melakukan apa saja terhadap perempuan termasuk kekerasan (Syafiq, 2001). Kecendenungan pariarkhis dalam fikih didasari setidaknya oleh tiga aspek penting, yaitu (1) aspek geneologis; fikih tumbuh dan berkembang di tangan kaum laki-laki dan dalam sebuah jaringan relasi kekuasaan laki-laki, sehingga wajar bila yang menjadi grand narrative adalah wacana laki-laki, (2) aspek kultural; ulama pembentuk wacana fikih mayoritas tumbuh di wilayah geografis yang bercorak patriarkhis, 
sehingga wajar bila fikih kemudian bercorak patriarkhis, dan (3) aspek transmisi keilmuan; agen penyebaran fikih pada umumnya adalah laki-laki, misalnya para imam mazhab adalah laki-laki dan belajar dari guru laki-laki serta beriburibu muridnya juga laki-laki. Dengan demikian bisa dipahami kenapa fikih Islam mengandung bias laki-laki (patriarkhis) dan tidak sensitif terhadap gender equity. Agar fikih Islam lebih responsif terhadap isu jender, perlu dikembangkan sebuah Fiqh al-Nisa (fikih feminis) yang berperspektif jender, dalam arti membentuk sebuah disiplin ilmu fikih yang dirumuskan untuk kepentingan kaum perempuan. Agenda tersebut diharapkan menjadi sebuah paradigma pemberdayaan perempuan menuju suatu masyarakat madani (civil society), yang para anggotanya memiliki kedudukan yang setara satu sama lain (Syafiq, 2001).

Teori hukum feminis memang bertujuan menggugat diskursus publik tentang topik-topik hukum yang dilakukan hampir sepenuhnya oleh ahli hukum laki-laki yang berpikir dan menulis dari perspektif laki-laki, sebuah perspektif yang mencerminkan dominasi yang diasumsikan dan dipertegas sebagai sebuah hal yang "alamiah". Dengan demikian gerakan hukum feminis ini bertujuan melakukan sebuah revolusi ideologi yang dirancang untuk menggantikan struktur hukum dan politik yang didominasi kaum laki-laki. Penolakan terhadap teori hukum patriarkhis diikuti dengan sebuah upaya membangun teori hukum baru yang diciptakan untuk memperhatikan aspirasi dan kepentingan kaum perempuan dan yang mengakui kebutuhan akan sebuah "masyarakat ideal" di mana semua individu dapat merealisasikan potensi dasar kepribadiannya (Curzon, 1995).

Dalam konteks ini, kajian lritik hukum feminis menyumbangkan sebuah metode yang berguna. Metode tersebut dipandang penting sebagai sarana untuk membeberkan orientasi patriarkhis yang samar maupun yang terang-terangan dalam hukum, dan kerugian serta proses peminggiran yang sering diderita oleh kaum perempuan. Katherine T. Bartlett menawarkan tiga unsur yang menandai sebuah teori hukum feminis, yaitu:

- Menanyakan "pertanyaan perempuan," yaitu sejauh mana keberadaan perempuan dan pengakuan terhadap pengalaman perempuan dimasukkan ke dalam sistem hukum.

- Penalaran praktis feminis, artinya sebuah penalaran yang beranjak dari konteks dan nilai perbedaan serta pengalaman dari kelompok sosial yang tak berdayà.

- Peningkatan kesadaran, artinya penelusuran terhadap pengalaman kolektif perempuan dengan cara saling berbagi pengalaman masing-masing. 
Di atas landasan teori ini, teori hukum feminis berupaya menegaskan perspektif perempuan terhadap hukum dan akhirnya memberdayakan perempuan dalam perkembangan di masa depan atau dalam reformulasi hukum di masa depan (Katherine, 1970).

Dari perspektif feminis, dominasi laki-laki dalam hukum, seperti halnya struktur kekuasaan lain yang menjadi bahan kajian analisa hukum yang kritis, mengambil bentuk yang samar atau terang-terangan, atau bahkan tidak diketahui bentuknya. Diskriminasi terang-terangan terhadap perempuan, misalnya seperti yang dipraktekkan pada masa lalu, juga terus berlanjut hingga sekarang.

Rintangan besar yang dihadapi oleh kaum feminis adalah bagaimana menjadikan mereka yang memegang kekuasaan menyadari bahwa norma-norma yang mereka gunakan bagaimanapun hanyalah norma yang mereka pilih, dan bahwa kebanyakan norma tradisional pada kenyataannya hanya menguntungkan laki-laki dan merugikan perempuan serta memperkuat tatanan sosial tradisional yang membatasi kebebasan perempuan. Dalam mengevaluasi norma-norma tradisional, hal yang dipandang normal adalah hal yang telah dilakukan oleh semua orang, dan ia berarti status quo. Kaum feminis telah menemukan bahwa norma-norma tersebut sulit digugat ketika perbedaan fisik maupun sosial antara laki-laki dan perempuan tampak nyata sekali, dan ketika kepentingan laki-laki dan perempuan dipandang saling bertentangan. Pada kasus semacam itu, status quo itu sendiri yang merugikan kaum perempuan, dan dalam mengatasi rintangan tersebut diperlukan sebuah pendekatan yang lebih radikal untuk menggugat norma-norma dasarnya (Patricia,1995).

\section{Gugatan Terhadap Teori Hukum Feminis}

Seperti yang bisa kita saksikan, gerakan feminis bukan hanya satu, tapi banyak; demikian pula halnya, teori hukum feminis bukan hanya satu, tapi banyak. Ada beberapa persoalan yang terlontar tentang gerakan feminis dalam hukum, yaitu apa sebenarnya kesamaan dari berbagai pandangan yang berbeda itu sehingga ia bisa mengikat kesamaan mereka dan membedakan mereka dari teori-teori hukum lainnya? Dengan kata lain, apa yang membuat mereka semua dipandang sebagai feminis? Kedua, apa yang mereka katakan tentang hukum? Dengan kata lain, apa yang membuat mereka dipandang sebagai teori hukum? Pertanyaan-pertanyaan tersebut bersumber dari keberatan-keberatan utama yang diarahkan kepada teori hukum feminis, yaitu (1) bahwa ia bukanlah teori hukum "yang sejati"; (2) bahwa ia secara khusus tidak bersifat feminis. 
Keberatan-keberatan tersebut benar-benar menantang keberadaan atau legitimasi teori hukum feminis sebagai sebuah disiplin keilmuan filosofis.

Apa yang membuat teori hukum feminis dipandang sebagaiteori hukum? Karena teori hukum merupakan sebuah analisa tentang hubungan, konsep dan prinsip hukum yang mendasar, dan teori hukum feminis yang memandang dirinya sebagai teori hukum pada kenyataannya terlibat dalam analisa semacam itu, maka pertanyaan sebenarnya adalah mengapa muncul keberatan untuk memasukkannya sebagai sebuah teori hukum? Disebutkan bahwa teori hukum feminis merupakan sebuah istilah yang kontradiktif. Dikatakan bahwa teori hukum seharusnya merupakan sebuah analisis yang netral terhadap prinsipprinsip hukum yang universal, sehingga karena gerakan feminis memiliki kepentingan sendiri, maka ia akan menghasilkan teori hukum yang mengabdi kepada kepentingannya itu, yang jelas merupakan sebuah bentuk kontradiksi istilah. Namun argumentasi tersebut keliru dalam dua premis utamanya: (1) ia mengasumsikan feminisme sebagai sebuah gerakan kepentingan yang memihak, dan itu adalah asumsi yang keliru, dan (2) ia mengasumsikan bahwa teori hukum bersifat netral (artinya, bebas dari ikatan moral dan politik), dan itu juga merupakan asumsi yang keliru.

Jawaban terhadap asumsi pertama adalah bahwa teori hukum feminis sama-sama memiliki kepentingan seperti halnya teori hukum yang mengaku universal, yang pada kenyataannya, merupakan topeng patriarkhis yang tampak sebagai analisa objektif terhadap prinsip-prinsip dan konsep-konsep hukum yang netral. Pada kenyataannya, kebanyakan teori hukum feminis dicurahkan untuk membuktikan bahwa teori hukum dan hukum tradisional tidak netral dan tidak universal, tapi mengandung bias yang mendukung budaya yang dominan sambil mengorbankan budaya lain yang marjinal (Smith, 1993; Minow, 1990). Oleh karena itu keberatan terhadap legitimasi teori hukum feminis ini bertumpu pada penolakan dan pengabaian terhadap klaim utama feminisme tentang karakteristik teori hukum dan hukum. Jadi, keberatan tersebut merupakan wujud dari kesalahan mendasar dalam memahami tujuan teori hukum feminis, yang tidak dimaksudkan untuk membangun ulang institusi-institusi hukum agar memihak kaum perempuan. Ia dimaksudkan untuk membangun ulang institusi-institusi hukum agar tidak merugikan perempuan. Artinya, ia dimaksudkan untuk menghapus bias yang merugikan perempuan. Jadi, sementara feminisme memiliki kepentingan sendiri, teori hukum feminis juga memiliki kepentingan dalam arti kepentingan untuk mempertahankan diri, dan mengedepankan keadilan, bukan hak istimewa. Oleh karena itu, asumsi bahwa feminis memiliki agenda kepentingan yang tidak sah merupakan asumsi yang keliru. 
Adapun jawaban terhadapan keberatan kedua bahwa teori hukum bersifat netral adalah bahwa keberatan tersebut bertumpu pada penafsiran khusus tentang batasan/arti dari teori hukum. Gagasan tentang teori hukum dalam penggunaannya dewasa ini dapat dibagi ke dalam pengertian yang sempit dan pengertian yang luas. Secara umum, teori-teori hukum bertumpu pada teoriteori politik. Misalnya, teori-teori politik liberal, Marxis dan sosialis melahirkan pandangan-pandangan yang terkait dengan teori-teori hukum. Jelaslah bahwa teori hukum dalam pengertian luas tidak memiliki kenetralan dalam teoriteorinya. Tapi justru sebaliknya.

Kebanyakan (meskipun tidak semua) teori hukum feminis dihubungkan dengan satu atau beberapa teori-teori politik itu. Misalnya, kaum feminis liberal sejak Mary Wollstonecraft selalu berargumen bahwa nilai-nilai liberal harus diterapkan secara adil terhadap perempuan seperti yang diungkapkan oleh Gutmann (1980). Kaum feminis Marxis berargumen bahwa analisa kelas yang dikemukakan oleh Marx harus diterapkan secara adil dalam persoalan jender seperti yang ditulis oleh Davis (1981). Kaum feminis sosialis berargumen bahwa prinsip-prinsip sosialis harus digunakan untuk meredam penindasan seksisme* seperti yang terdapat dalam tulisan Jagger (1983).

Teori-teori feminis seringkali merujuk pada penyingkiran terhadap perempuan atau keberadaan diskriminasijender dalam teori-teori politik pada umumnya. Teori hukum feminis dapat digabungkan dengan sejumlah pandangan politik lainnya. Ia bisa menjadi pragmatis seperti dalam tulisan Radin (1990), menjadi postmodern seperti pada tulisan Frug (1992), benarbenar menjadi radikal seperti pada tulisan MacKinnon (1989), atau tidak terikat ke dalam teori-teori tertentu seperti dalam tulisan Minow (1990). Jadi, tidak ada teori hukum feminis yang tunggal, tidak ada pandangan politik tunggal yang terkait dengan feminisme, kecuali feminisme itu sendiri, yang juga merupakan pandangan yang bersifat politis (pandangan yang mengedepankan kebebasan dan keadilan terhadap perempuan). Jadi, semua teori feminis bersifat politis. Namun, semua pandangan ini cocok dengan teori hukum dalam pengertian luas.

Namun, ada juga pengertian sempit dan teknis dari teori hukum, yang terkadang disejajarkan dengan semua teori hukum.Jadi, legitimasi teori hukum dalam pengertian luas terkadang dipertanyakan, dan itulah landasan yang digunakan untuk mengklaim bahwa teori hukum feminis bukanlah teori hukum "sebenanya." Ia tidak cocok dengan teori hukum dalam pengertian sempit. Tapi pengertian sempit teori hukum sendiri - setidaknya dalam bentuknya yang menolak legitimasi teori hukum feminis - terbuka untuk dipertanyakan. 
Pengertian sempit teori hukum terkait secara tradisional dengan pertanyaan: apa arti hukum? Ketika menjawab pertanyaan itu, para filsuf berkonsentrasi pada konsep tentang hukum, hubungan hukum, dan fungsi hukum, terutama penalaran hukum. Secara historis, terdapat tiga teori utama yang dikedepankan untuk menjawab persoalan-persoalan tersebut.

Yang tertua, yaitu hukum alam, biasanya mendefinisikan hukum sebagai sebuah aturan logika yang disebarluaskan untuk kebaikan bersama oleh mereka yang memiliki otoritas untuk melakukannya. Hukum alam berpandangan, di antaranya, bahwa terdapat kaitan yang penting antara hukum dan moralitas, sehingga hukum yang tidak bermoral tidak dipandang sah dan tidak mengikat.

Pandangan kedua, yaitu positivisme hukum, yang merupakan pandangan yang dominan pada abad ke-19, menolak pandangan hukum alam karena dianggap telah mengacaukan antara hukum pada kenyataannya dengan hukum yang seharusnya, dan berupaya membangun definisi hukum sendiri yang bersifat netral dari bias nilai. Para penganut positivisme hukum kini pada umumnya mendefinisikan hukum sebagai sebuah sistem aturan yang dikeluarkan melalui prosedur-prosedur yang memiliki otoritas, yang diakui mengikat dan ditaati oleh semua masyarakat.

Teori yang ketiga, realisme hukum, yang merupakan perkembangan abad ke-20, mengajukan keberatan terhadap pendekatan hukum alam yang dipandang sangat samar dan terlalu bersifat metafisik, dan juga terhadap pendekatan kaum positivis yang dipandang terlalu kaku dan abstrak. Dengan berargumen bahwa hukum pada dasarnya pasti bersifat politis, para penganut realisme hukum ini mendefinisikan hukum secara garis besarsebagai sebuah metode penyelesaian sengketa dengan membawanya ke lembaga pemerintah, terutama pengadilan; atau lebih ringkas lagi, mereka mengklaim bahwa hukum adalah apa yang diputuskan oleh hakim. Teori yang telah dikenal baik initerus memperdebatkan karakteristik hukum yang paling mendasar dan fungsi semestinya dari teori hukum dewasa ini.

Dari sana kita dapat melihat bahwa teori hukum tradisional telah lama terpisah ke dalam dua sub-kategori utama: teori hukum normatif dan teori hukum deskriptif. Pembagian ini dilakukan pertama kali oleh John Austin, seorang penganut positivisme hukum abadke-19 yang mengabdikan kuliah-kuliah terkenalnya untuk menentukan wilayah-wilayah teori hukum. Menurut Austin, wilayah teori hukum yang semestinya adalah pada analisa deskriptif terhadap hukum positif, konsep-konsep serta hubungan-hubungan utamanya. Analisa normatif tentang hukum, menurutnya, merupakan wilayah kecakapan legislasi, 
bukan teori hukum, dan keduanya tidak boleh dicampuradukkan, seperti halnya tidak boleh mencampuradukkan hukum dengan moralitas.

Pengaruh yang begitu kuat dari pandangan ini dapat disaksikan dalam definisi resmi tentang teori hukum (yurisprudensi) pada Black's Law dictionary:

Teori hukum adalah ilmu hukum yang berfungsi menjamin prinsipprinsip yang menjadi dasar aturan hukum, sehingga ia tidak hanya mengklasifikasikan aturan tersebut dalam urutan yang semestinya, tapi juga menetapkan cara-cara memasukkan kasus-kasus yang meragukan ke dalam aturan-aturan yang cocok. Teori hukum lebih merupakan ilmu hukum fornil ketimbang ilmu hukum materil. Ia tidak memiliki perhatian langsung terhadap persoalan-persoalan tentang kebijakan moral atau politik, karena persoalanpersoalan tersebut merupakan wilayah etika dan legislasi.

Perhatikan bahwa definisi tersebut dengan aman telah menyelesaikan kontroversi panjang dan berlarut-larut di antara para teoritisi hukum alam dan positif, dengan menjadikan positivisme sebagai satu-satunya teori hukum sejati. Meskipun demikian, entri pada kamus itu menunjukkan kuatnya pengaruh positivisme hukum dalam pemikiran hukum. Pandangan inilah yang memberikan landasan bagi keberatan bahwa feminisme, karena tidak netral, bertentangan dengan teori hukum.

Menurut Black's Law Dictionary, teori hukum alam bukanlah teori hukum (demikian pula halnya dengan realisme hukum), sehingga kaum feminis juga tidak perlu merasa terganggu jika teori-teori mereka tidak dipandang sebagai teori hukum atas dasar alasan yang sama. Tapi butir penting dari Black's Law Dictionary adalah bahwa, dalam upayanya untuk bersikap netral, kamus tersebut menutup mata dengan biasnya terhađap semua teori yang ada, kecuali positivisme hukum, yang mendefinisikan teori hukum berdasarkan asumsiasumsi positivisme hukum, sehingga sulit untuk dikatakan sebagai definisi yang netral.

Apa yang ditunjukkan dari paparan di atas adalah bahwa berdasarkan karakteristik hukum yang bersifat politis itu, teori hukurn sama sekali tidak bisa dipandang netral, karena memperdebatkan dan menyelidiki dampak-dampak politis hukum merupakan persoalan sentral dalam teori hukum. Jadi, teori hukum tidak bisa dikatakan, dan tidak dapat, bersifat netral, dan hal itu menunjukkan bahwa asumsi-asumsi yang mendasari keberatan terhadap legitimasi teori hukum feminis terbukti keliru. Jadi teori hukum feminis benar-benar merupakan teori hukum, atau jika tidak, maka hukum alam juga tidak bisa dikatakan sebagai teori hukum. Hal ini tidak berarti bahwa keduanya tidak mungkin salah. Pendukung positivisme hukum dapat mengklaim bahwa hukumalam keliru, 
tapi tidak dapat mengklaim bahwa ia bukanlah teori hukum. Demikian juga halnya dengan para pengritik feminisme.

Pertanyaan yang lebih sulit adalah apa yang membuat teori hukum feminis dipandang sebagai feminis? Keragaman yang demikian besar dalam feminisme telah menggiring para pengritik (bahkan dari kalangan feminis sendiri) untuk berargumen bahwa kaum feminis tidak memiliki kesamaan perspektif. Tidak ada ciri khas yang membedakan teori hukum feminis dari teori hukum lainnya. Semua gerakan feminis pada dasarnya bisa direduksi ke dalam teori-teori yang melukiskan berbagai sisinya. Feminisme liberal bisa dikerucutkan menjadi liberalisme; feminisme post modern bisa direduksi menjadi post modernisme, dan sebagainya. Jadi, para penggugat mengklaim bahwa gerakan feminisme tidak menawarkan gagasan baru, atau teori tersendiri. Ia tidak lain dari pada bentuk penerapan dari teori-teori lama terhadap persoalan khusus menyangkut ketertindasan perempuan.

Lebih jauh lagi dikatakan bahwa gerakan feminisme tidak mewakili pandangan semua perempuan. Feminisme, jika bisa dikatakan sebagai sebuah pandangan, merupakan pandangan segelintir perempuan yang berusaha memaksakan pandangan tersebut kepada semua orang. Kenyataannya adalah bahwa mayoritas perempuan di dunia idak setuju dengan pandangan kaum feminis atau bahkan tidak pernah memikirkan persoalan-persoalan yang dimunculkan oleh kaum feminis. Jadi sungguh sangat problematis bagi para feminis jika mereka hendak mengklaim sebagai representasi dari semua perempuan.

Tidak diragukan lagi bahwa perempuan sama beragamnya seperti halnya umat manusia. Perempuan bisa saja kaya, miskin, kuat, lemah, mendominasi, pasrah, kelas atas, kelas bawah, rasional, irasional, dan lain-lain, yang daftarnya bisa sangat panjang. Perempuan merupakan anggota dari semua jenis ras, agama, kebangsaan, kelas atau kelompok etnis. Jadi apa kira-kira perspektif seluruh perempuan yang merupakan landasan rekaan dari gerakan feminis? Apa kesamaan pandangan yang dimiliki kaum perempuan?

Apa unsur kesamaan antara diri kita dengan perempuan tuna wisma yang berpapasan dengan kita di Terminal Arjosari, atau perempuan lain yang tidak kita jumpai di kampung halaman kita? Apa kesamaan antara para profesor universitas dengan para tuna susila, pecandu obat-obatan, tokoh masyarakat, atau eksekutif perusahaan, kasir atau orang cacat yang kesepian dan terluntalunta tanpa perawatan? Bagaimana seseorang memandang dirinya berbicara atas nama mereka? Perempuan-perempuan di Afrika Selatan, Bangladesh, 
bekas Yugoslavia, China, hutan Brazil, dan pedalaman Australia, semuanya adalah perempuan. Apakah mungkin jika mereka semua memiliki kesamaan?

Kesamaan apa yang dimiliki setiap perempuan, apapun ras, kelas, agama, status, kebangsaan, etnis atau latar belakang mereka? Semua perempuan hidup di bawah dunia patriarkhis. Itulah kesamaannya. Semua perempuan menjalankan fungsinya dalam lingkungan yang didominasi sistem patriarkhis. Sistem tersebut tidak terhindarkan, seperti udara. Kita makan, tidur, bernafas seperti halnya laki-laki. Jadi semua perempuan berperan dalam sebuah pandangan dunia yang membentuk gambaran tertentu tentang realitas - sebuah gambaran yang secara mendalam dan sistematis mengandung bias jender. Itulah pandangan para feminis yang memandang bahwa jender sendiri merupakan konstruksi sosial yang didasarkan pada dan mencerminkan seksisme, yaitu pandangan tentang dominasi kaum laki-laki dan subordinasi kaum perempuan - sebagai bentuk pembenaran terhadap akibat dan kebutuhan dan perbedaan alamiah -, otonomi kaum laki-laki di tengah keterbatasan kaum perempuan sebagai pembenaran terhadap perlindungan bagi perempuan - , dan pengagungan terhadap kaum laki-laki di samping penurunan harkat perempuan - biasanya sebagai pembenarannya digambarkan sebuah dunia yang netral nilai (McKinnon, 1989).

Salah satu persoalan yang dihadapi kaum feminis adalah bahwa semua gambaran tentang patriarkhi pasti akan dipandang terlalu menyederhanakankarena sistempatriarkhis menpakan pandangan yang mendunia. Persoalannya sangat rumit luar biasa. Sebagai perbandingan, jika kita bertanya kepada sepuluh orang untuk menggambarkan Indonesia (atau sebuah entitas rumit lain) misalnya, maka kita akan mendapatkan sepuluh gambaran yang berbeda. Kesepuluh gambaran itu bisa jadi semuanyabenar. Namun, semuanya pasti tidak lengkap. Tidak satupun gambaran tersebut yang dapat memberikan gambaran terbaik yang mencakup semua yang dikehendaki. Dan mereka bisa saja sama sekali berbeda satu sama lain, namun pendapat mereka semua tepat, karena yang membuatnya berbeda adalah fokis, tujuan, atau karakteristik mereka. Namun, sistem patriarkhis jauh lebih kompleks dari pada sebuah negara atau budaya tertentu. Ia merupakan sebuah pandangan yang mendunia, dengan jutaan dampak dan pengaruh, yang telah membentuk realitas sejak zaman pra-sejarah tanpa pernah digugat, ditentang dan dirubah secara serius hingga paruh kedua abadke-20. Ia merupakan pandangan dunia yang sangat efektif sebagai sebuah ideologi paling sempurna yang pernah dibangun. Ia membentuk harnpir semua dan apapun yang ada dalam batas imajinasi dan realitasnya. Hampir tidakada yang luput dari sentuhan sistem patriarkhis. Gambaran menyelunuh tentang sesuatu semacam itu sangat tidak mungkin dilakukan. Jadi tidak mengejutkan 
bahwa kaum feminis yang berbeda-beda itu menyuguhkan gambaran yang berbeda tentang patriarkhi dan menerapkan pendekatan yang berbeda terhadapnya.

Namun, semua itu tidak berarti bahwa karena patriarkhi merupakan pandangan dunia yang kompleks dan yang tidak bisa digambarkan secara menyeluruh, maka tidak ada sesuatu yang dikatakan sebagai sistem patriarkhis, atau bahwa perempuan tidak berada di bawah sistem tersebut. Patriarkhi merupakan subordinasi sistematis kaum perempuan terhadap kaum laki-laki, dan bahwa ia merupakan pengalaman yang dirasakan oleh semua perempuan. Pendapat semua perempuan menunjukkan bahwa mereka berada pada posisi subordinasi atas dasar jenis kelamin, apapun perbedaan yang mereka miliki.

Kajian hukum feminis memandang adanya kesamaan pengalaman kaum perempuan, yaitu bahwa mereka hidup di bawah dunia patriarkhis yang memposisikan mereka sebagai kelompok kelas dua, dan kesamaan pada semua gerakan feminis adalah penolakan mereka terhadap pandangan dunia semacam itu. Fokus dan hasil dari penolakan tersebut bisa mengambil bentuk yang sangat beragam. Kaum feminis bisa saja tidak sependapat satu sama lain tentang unsurunsur apa yang menjadi landasan penolakan mereka terhadap dominasi seksisme, atau tentang pendekatan mana yang tampaknya mungkin untuk meningkatkan kondisi perempuan, atau kondisi apa saja yang paling rentan disalahgunakan atau disalahtafsirkan. Mereka mungkin berbeda pendapat tentang unsur-unsur apa saja yang merupakan hakikat pesoalan tersebut, atau apakah persoalan in memiliki esensinya sendiri. Meskipun demikian, semua teori feminis dimaksudkan untuk membebaskan kaum perempuan dari dominasi seksisme dalam berbagai bentuknya.

Dominasi paham seksisme muncul dalam berbagai bentuk. Ia bisa dijumpai dalam perilaku sosial, seperti pemerkosaan, pemukulan terhadap isteri, pelecehan seksual, praktik dalam lapangan kerja, harapan pendidikan, rancangan ruang kerja, iklan, hiburan dan tanggung jawab dalam keluarga untuk menyebutkan beberapa saja di antaranya. Kebanyakan perilaku sosial itu tercermin dalam hukum. Perilaku tersebut merupakan bagian dari jutaan dampak sistem patriarkhis. Dan semua dampak tersebut menjadi wilayah kajian teori feminis. Itulah yang membuatnya menjadi begitu menarik.

\section{Kesimpulan}

Dalam tataran teori hukum, meskipun bentuknya beragam, pemikiran kaum feminis memiliki dua karakteristik yang bisa menyatukan dan saling terkait 
erat (Ian McLeod, 1999). Pertama, gagasan bahwa masyarakat, dan terutama tatanan hukum, bercirikan patriakhis. Pergulatan menentang patriarkhi menandai tujuan, argumentasi dan metodologi hukum feminis. Kedua, ia berusaha menganalisa kontribusi hukum dalam membangun, memelihara, memperkuat dan melestarikan sistem patriakhis, dan ia berupaya mengakhiri dan akhimya melenyapkan sistem tersebut.Patriarkhi, menurut para ahli hukum feminis, giat menanamkan dan mempropagandakan ideologinya, yaitu bahwa memerangi pandangan-pandangan patriarkhis merupakan bentuk penolakan terhadap ketentuan alam; bahwa menyuarakan sudut pandang yang mempertanyakan makna-makna yang dilekatkan kepada konsep ketidaksetaraan berarti lari dari takdir; bahwa menyangsikan dasar-dasar pembedaan/ diskriminasi, misalnya dalam peran di dalam dan di luar rumah tangga, berarti sebuah kekeliruan dalam memahami karakteristik laki-laki dan perempuan yang sebenarnya, dan sebagainya.

Analisa-analisa feminis telah menawarkan kritik yang penting dalam beragam konteks, dari analisa yang luas dari sudut politik hingga teori kultural untuk menganalisa disiplin akademis yang khusus. Sebagian teori hukum feminis merupakan analisa terhadap sejauh mana sistem hukum merefleksikan dan memperkuat perspektif laki-laki. Kesamaan yang terdapat dalam teori hukum feminis adalah perlawanan mereka terhadap gagasan patriarkhis yang mendominasi masyarakat secara umum, dankhususnya terhadap sistem hukum. Perbedaan di kalangan teoritisi hukum feminis mencerminkan sebuah perbedaan penekanan atau perspektif dalam menggambarkan berbagai aspek dan dampak dari sistem patriarkhis, perbedaan tentang fokus perhatian, dan perbedaan dalam strategi mengatasi persoalan patriarkhi. Jadi, keragaman dalam teori feminis merupakan bagian dari cerminan sistem patriarkhis yang telah merambah ke berbagai lini kehidupan beserta beragam dampaknya.

\section{DAFTAR PUSTAKA}

Bartlett, Katherine T., "Feminist Legal Method" (1970), Harvard Legal Review 103.

Caudill, David S. dan Steven Jay Gold (eds.), Radical Philosophy of Law. Contemporary Challenges to Mainstream Legal Theory and Practice, New Jersey: Humanities Press, 1995.

Curzon, L.B., Jurisprudence, London: Cavandish Publishing Ltd., 1995.

Davis, A., 1981: Women, Race and Class, New York: Random House. 
Frug, M.J., 1992: Postmodern Legal Feminism, New York: Routledge.

Gutmann, A., 1980: Liberal Equality, New York: Cambridge University Press.

Hasyim, Syafiq, Hal-Hal Yang Tak Terpikirkan Tentang Isu-IsuKeperempuanan Dalam Islam: Sebuah Dokumentasi, Bandung: Mizan, 2001.

Jaggar, A., 1983: Feminist Politics and Human Nature, Totowa, New York: Rowman \& Alleneld.

MacKinnon, C., 1987: Feminist Unmodified: Discourse on Life and Law, Cambridge, Massachusetts: Harvard University Press.

McCoubrey, Prof. Hilaire dan Dr. Nigel D. White, Textbook On Jurisprudence, London: Blackstones Press Ltd, 1999.

McLeod, Ian, Legal Theory, London: Mac Milan Press Ltd., 1999.

Minow, M., 1990: Making All the Difference, Cambridge, Massachusetts: Harvard University Press.

Radin, M.J., 1993: "The pragmatist and the feminist." California Law Review, 63. Dicetak ulang dalam P. Smith (ed.), Feminist Jurisprudence, New York: Oxford University Press.

* Penulis adalah dosen Fakultas Tarbiyah UIN Malang dan telah menyelesaikan pendidikan Pasca Sarjana di Leiden Universiteit tahun 2000.

* Seksisme merupakan pandangan yang menyatakan bahwa laki-laki lebih tinggi derajatnya dari perempuan. 